wealth, the U.S.S.R. and China. The thirty-four specific conclusions of this study are set forth in its final chapter, following chapters in which the Pacific area is considered as a region, the main features of a design of security are outlined, and the position of each of the four major Powers is examined under the sub-title "A Speculative Appreciation of Certain Power Factors in the Pacific". British interests in the Pacific are discussed in a separate chapter, leading to the conclusion that Great Britain is a Power with so substantial a concern in the region that, in partnership with the Pacific Dominions of the British Commonwealth, she is bound to play a large paty in the future history of that Ocean.

\section{Sky Fantasia}

RoBert Rulles, Hayden Planetarium, has an article With this title in Sky and Telescope of June, and antong a number of celestial phenomena that pest interesting and sometimes puzzling features if Hcluded the apparently greater diameter of the rilng moon compared with the diameter when it has attained a higher altitude. Some text-books still repeat the old explanation, discarded many years ago, that the horizon moon is so situated that its size can be easily compared with terrestrial objects, but at higher altitudes we are deprived of these for comparison. Anyone can disprove this theory if he observes the moon near the horizon at sea, where no terrestrial objects are available for comparison. Yet the moon looks as large when rising or setting over the sea as it does when viewed on the land. Some years ago, Drs. E. G. Boring and A. H. Holway, two Harvard psychologists, after a series of experiments, concluded that the illusion is due to a physiological cause. It has been found that objects viewed straight ahead appear larger than do those of the same size in positions where the eye must be raised to see them. Although this theory is almost certainly the correct one, the basic causes are still somewhat of a mysteŕy. The illusion can be observed in the constellations also, such as the Plough, which appears very much larger when low on the horizon than when high in the sky. Other groups of stars, like the Great Square of Pegasus, the Northern Cross, etc., exhibit the same phenomenon. An experiment which can be performed by anyone on some of these groups of stars, or preferably on the moon, will show that the old theory is incorrect. When the moon is near the horizon, gauge it between the thumb and forefinger and notice it shrinking; as the finger and thumb are separated it appears to swell again. This experiment is referred to elsewhere in the same issue of Sky and Telescope, and shows that the illusion is due to a physiological or psychological cause.

\section{Surface-Activeygents}

THE eight papers, together with the introductory address by iñ. L. Anson, presented at the two-day conferens on 'Surface-Active Agents' held by the Paysid. and Chemistry Section of the New York A fademy of Sciences in January 1945, have now been published (Ann. New York Acad. Sci., 46, 347; 1946). Almost all the surface-active agents referred to were water-soluble substances which, even in small conceptrations, lower the surface tension of water considerably. The properties of surface-active agents, how they are measured and how they are related to structure, were the topics discussed on the first day of the conference. Papers on these subjects were contributed by A. W. Ralston, E. K. Fischer and D. M. Gans, D. Price, and L. Shedlovsky. On the second day, the applications of surface-active agents to biology, medicine and industry were dealt with, E. I. Valko and R. D. Hotchkiss lecturing on the biological and medical applications; M. H. Hassialis and R. R. Ackley on the industrial applications. In the introduction, it is pointed out that although surface-active agents have been known for some time as chemical substances, it is only relatively recently that they have become available as cheap commercial compounds. Many such agents have been prepared and many industrial applications discovered, mostly in industrial laboratories, but basic scientific work on pure substances has been very greatly neglected. Indeed, it was lack of sufficient knowledge of the properties of pure surface-active agents that prevented any useful theoretical discussion of the relation between structure and properties. The object of the conference was to stimulate interest and to put the understanding of surface-active agents and their applications on a better scientific basis; the publica. tion of the proceedings ' this conference on surfaceactive agents should be of considerable value in guiding workers in this field as to the choice of suitable research problems.

\section{War-time Activity of the Leicester Museum rand} Art Gallery

That it is gossible or regional museum under active adnin tratio to fulfil and even increase its interests ufder difficulties of war-time conditions has beep anply proved by the Leicester City Museum ar Wit Gallery. The fortieth annual report (April 1, 19 13 -March 31, 1944 ; recently received) to the City Council. shows, for example, that in that year the Geological Department, besides giving technical assistance in connexion with war-time industrial developments, provided special courses of instruction for members of the Forces; that the Department of Botany arranged topical exhibits in relation to war. time gardening, food values, medicinal herbs, etc., and that the Schools Service was extended to units of H.M. Forces stationed in the Leicester area, and to the development of children's clubs in art, science and drama. In addition, several special exhibitions of wide public interest were a prominent feature of the period. The R.A.F. "Wings for Victory" Exhibition drew 36,306 visitors, and the "City Planning" Exhibition, which was arranged in collaboration with various other Corporation Departments of Leicester City, drew 17,574 visitors. It is of interest to note that the general policy of the year was one directed at the "maintenance of public good spirits and morale". Towards this end, several other exhibitions of topical, art and domestic interest were arranged, while lectures and the weekly lunch-time concerts continued to be regular features. The bold and exploratory activity shown by the Leicester Museum throughout the war years has probably been watched with interest by other museum administrators. Many new methods of direct public appeal have been tried out and, judging from the attendance figures shown on p.15 of the present report, these have met with considerable success.

\section{British Pryological Society \\ A Meering of the British Bryological Society was held In London during September 27-28. After the meting there was a dinner to celebrate the jubilee}


of the Society (founded in 1896 as the Moss Exchange Club), at which Sir Clive Forster-Cooper and Dr. John Ramsbottom were guests of honour. During the afternoon of September 27 the meeting was held (by kind permission of the director) in the Board Room of the Natural History Museum. Prof. T. M. Harris, of the University of Reading, read a paper on the fossil liverwort Naiadita, and Miss Grace Wigglesworth, formerly of the University of Manchester, on reproduction in Polytrichum commune. Among the exhibits was part of the herbarium of the late Mr. H. N. Dixon, a former president of the Society. On September 28 there was an excursion to Eridge and Harrison's Rocks, near Tunbridge Wells, and the rich and interesting bryophyte flora of the sandstone was seen at its best ; Pallavicinia Lyellii, Odontoschisma denudatum, Orthodontium gracile and Dicranum Scottianum were among the interesting species found. In a stubble field near Eridge a rich flora of ephemeral bryophytes was seen, for which the wet season was doubtless responsible.

\section{University of Leeds}

AT a mofting of the Council held on October 16, it was aynounced that Imperial Chemical Industries, Ltd. have given $£ 2,000$ to establish a research school in the Department of Biomolecular Structure, and the Rockefeller Foundation has given 10,000 dollars for research under the direction of Prof. W. T. Astbury for the current academic year. The Yorkshire Copper Works have given $£ 300$ for 1946 and 1947 for award of a scholarship to students of pure and applied science, preferably metallurgy.

Dr. F. C. Happold, reader in biochemistry, has been appointed professor of biochemistry as from August 1. The title of emeritus professor has been cơferred upon Prof. J. H. Jones, professor of economics, and Prof. W. P. Milne, professor of mathematics, on their retirement.

Lord Halifax will give the fifth Montague Burton Lecture on International Relations on February 20, 1947.

\section{Earthquakes during August}

'ON August 2 earthquake near Copiapo in northern Chile hodits epicentre near lat. $27^{\circ} \mathrm{S}$., long. $70^{\circ} \mathrm{W}$. The destructive Dominican Republic earthquage af $17 \mathrm{~h}$. 51m. 07s. G.M.T. on August 4 had its epilentre near lat. $19 \cdot 3^{\circ} \mathrm{N}$., long. $69^{\circ} \mathrm{W}$., which is nine miles east of the Samana Peninsula. Strong aftershocks from this epicentre took place at $13 \mathrm{~h}$. $28 \mathrm{~m}$. 24s. G.M.T. on August 8 and 19h. 17.6m. G.M.T. on August 21. The earthquake of August 11 at 1h. 54.3m. G.M.T. had its epicentre in the Solomon Islands near lat. $8^{\circ} \mathrm{S}$., long. $155^{\circ} \mathrm{E}$., whereas that of August 15 at $15 \mathrm{~h} .23 \cdot 9 \mathrm{~m}$. G.M.T. had its epicentre near lat. $22^{\circ} \mathrm{S}$., long. $170^{\circ} \mathrm{E}$. All the above epicentres were determined by the U.S. Coast and Geodetic Survey in co-operation with Science Service and the Jesuit Seismological Association. The earthquakes of August 2, 8, 11 and 21, together with nine others, were registered by Mr. E. W: Pollard at Binstead, Isle of Wight.

\section{Agricultural Research Council: Post-graduate Scholarship Awards \\ THE fricultural Research Council announces the folowing awards of post-graduate scholarships in agrieultural science and in animal health, to take effect from the beginning of the academic}

year 1946. Such scholarships were last awarded in 1941, after which, as a war-time measure; they were discontinued. On this occasion the potential needs for specialist advisers in the National Agricultural Advisory Service were taken into account, as well as those of the research service. J. M. Barry, University of Oxford, a three-year research scholarship in animal biochemistry; J. R. S. Fincham, University of Cambridge, a three-year research scholarship in plant genetics; A. Ibbotson, University of Birmingham, a three-year research scholarship in entomology; D. J. R. Laurence, University of Cambridge, a three-year research scholarship in animal genetics; B. C. Loughman, University College of Wales, Aberystwyth, a three-year research scholarship in biochemistry; Miss M. T. Morton, University of Edinburgh, a oneyear research scholarship in plant pathology ; Miss U. Parsons, University of Cambridge, a three-year research scholarship in animal physiology; Miss J. N. Winfield, University of Leeds, a one-year research scholarship in plant physiology.

\section{The Night Sky in November}

Full moon ocers on $07.9 \mathrm{~d}$. 07h. 10m., U.T., and new moon on N. 23 d. 17h. 24m. The following copiunctiof with the moon take place: Nov. 14d. $20 \mathrm{~h})$ Satrurn $4^{\circ} \mathrm{S}$. ; Nov. 22d. 03h., Jupiter $2^{\circ} \mathrm{S}$.; Nd 24 d. 18h., Mars $0.5^{\circ} \mathrm{S}$. In addition to these Cofjunctions with the moon, the following conjunctions take place: Nov. 1d. 00h., Mercury in conjunction with Venus, Mereury $3 \cdot 2^{\circ}$. N. ; Nov. $6 d$. 08h., Venus in conjunction with Mars, Venus $5 \cdot 2^{\circ} \mathrm{S}$.; Nov. 15d. 01h., Mercury in conjunction with Mars, Mercury $1.0^{\circ} \mathrm{S}$. The following occultations of stars brighter than magnitude 6 take place, the latitude of Greenwich being assumed: Nov. 2d. 18h. 27.6m., 33 Capr. $(D)$; Nov. 5d. 22h. $11 \cdot 0 \mathrm{~m} ., 30$ Pisc. $(D)$; Nov. 6d. 00h. $22 \cdot 4 \mathrm{~m} ., 33$ Pisc. $(D)$; Nov. 7 d. $19 \mathrm{~h}$. $32 \cdot \operatorname{lm} ., \nu$ Pisc. $(D)$; Nov. 16d. 05h. 03.4m., $\eta$ Leon. $(D)$; Nov. 16d. 05h. 39.6m., $\eta$ Leon. $(R)$; Nov. 18d. 04h. 06.6m., ข Virg. $(D)$; Nov. 18d. 05h. $04.8 \mathrm{~m}$., $\vee$ Virg. $(R)$. Mercury sets at $17 \mathrm{~h} .05 \mathrm{~m}$. on Nov. 1 and can be seen in the western sky after sunset. The planet is in inferior conjunction on Nov. 21. Venus is in inferior conjunction on Nov. 17 and can be seen towards the end of the month in the eastern sky, rising about $1 \mathrm{~h} .40 \mathrm{~m}$. before the sun. Mars and Jupiter are unfavourably placed for observation. Saturn rises at $22 \mathrm{~h} .25 \mathrm{~m}$. and $20 \mathrm{~h} .32 \mathrm{~m}$. at the beginning and end of the month respectively and is stationary on Nov. 21. The stellar magnitude of the planet is 0.4 throughout the month. There will be a partial eclipse of the sun on Nov. 23, invisible at Greenwich but visible over parts of Canada and America.

\section{Announcements}

DR. FPRK HARTLEY, secretary of the Therapeutic Research Corporation of Great Britain, Ltd., has been appointed manager of the Scientific Services Department of British Drug Houses, Ltd.

A SERIES of discussion meetings on Wednesdays at 7.30 p p. under, the general title "The Outlook in has been arranged by the Society for Visiting Scientists, 5 old Burlington Street, London,-W.1. The first meeting (chairman, Dr. C. F. A. Pantin) will deal with biology (October 30), and the second (chairman, Prof. N. F. Mott) with physics (November 20). 